\author{
Wilken ENGELBRECHT \\ ORCID: 0000-0002-9058-8199 \\ Univerzita Palackého v Olomouci / Katolicki Uniwersytet Lubelski Jana Pawła II
}

Kateřina KŘÍŽOVÁ

ORCID: 0000-0002-7357-9530

Univerzita Palackého v Olomouci

\title{
Iets om over te praten. De problematiek van het voorzetselvoorwerp in het Nederlands en het Tsjechisch
}

\begin{abstract}
For foreign students, the prepositional object is among the most problematic syntactic features of the Dutch language, as its form presents strong similarities with the adverbial clause, but it has an object function. In some cases it is very difficult to even decide whether the prepositional phrase has an adverbial function or is an object comparable with the direct object. In this paper the Dutch prepositional object is compared with similar constructions in the Czech language. Furthermore, the function of the preposition and its categorisation are briefly discussed. The paper ends with some criteria for Czech-speaking students to recognize a prepositional object as such.
\end{abstract}

Keywords: prepositional object, adverbial clause, Dutch, Czech, traditional syntax.

\section{Afbakening van het onderwerp}

Het voorzetselvoorwerp behoort zeker niet tot de onderwerpen waar studenten wild van worden, althans niet in de zin van 'er graag mee bezig zijn'. Dat geldt bepaald niet alleen voor anderstalige studenten - ook studenten-moedertaalsprekers hebben ernstige problemen met dit zinsdeel dat tot de syntactische nachtmerries van menig scholier en student behoort. ${ }^{1}$ Dat heeft te maken met zowel

1 Zie bijv. het commentaar Het verraderlijke voorzetselvoorwerp op het later in dit artikel vermelde 'criteriadebat' in Taalprof Plein, gepost op 20 juni 2006 (http://taalprof.blogspot.com/2006/06/ het-verraderlijke-voorzetselvoorwerp.html). 
de gelijkenis van prepositionele objecten met bijwoordelijke bepalingen, als met hun functie als object. Voor de anderstalige student geldt bovendien dat er voor het begrip voorzetselvoorwerp als zodanig vaak geen equivalent als erkende syntactische categorie in het eigen grammaticale systeem bestaat. Dat is bijvoorbeeld het geval bij de West-Slavische talen.

In deze bijdrage wordt de situatie in het Nederlands met die in het Tsjechisch vergeleken om te bekijken hoe dit zinsdeel in beide talen fungeert. Hierbij beperken we ons tot het voorzetselvoorwerp in hoofd- en bijzinnen. De voorzetselvoorwerpszinnen die in het Nederlands een nog ingewikkelder probleem vormen zijn buiten beschouwing gelaten, temeer omdat beknopte bijzinnen in het Tsjechisch nauwelijks bestaan. ${ }^{2}$ Verder is uitgegaan van de traditionele syntaxis zoals die in de Algemene Nederlandse Spraakkunst (1997), ${ }^{3}$ bij Jan Luif, In verband met de zin (2011) en bij Willy Vandeweghe, Grammatica van de Nederlandse zin (2000) is beschreven. Voor het Tsjechisch is van vergelijkbare werken uitgegaan, met name de Mluvnice češtiny (1987) [Grammatica van het Tsjechisch, hierna MČ] die de functie van 'de Tsjechische $A N S$ ' heeft, ${ }^{4}$ van Petr Karlík e.a., Príručni mluvnice češtiny (2012) [Handboek van de Tsjechische grammatica, hierna $P M C ̌$ ] en tenslotte van Skladba češtiny (1998) [Zinsbouw van het Tsjechisch] van Miroslav Grepl en Petr Karlík.

In onze bijdrage beschrijven we eerst definities van het voorzetselvoorwerp in het Nederlands. Daarna bekijken we het syntactisch vergelijkbare verschijnsel in het Tsjechisch. Wij stippen kort het zogeheten 'criteriadebat' aan, een debat over welke criteria er zijn om een syntactisch verschijnsel in het Nederlands als 'voorzetselvoorwerp' aan te duiden. Ten slotte geven we in de laatste paragraaf 'Ter afronding' een overzicht en doen we voorstellen voor verder comparatief onderzoek.

2 Nederlandse beknopte bijzinnen moeten in het Tsjechisch vrijwel altijd als een 'gewone' bijzin worden vertaald. Bij voorbeeld: "Ik vroeg de studenten goed op te letten op de plaatjes" wordt vertaald als "Žádal jsem studenty, aby na obrázky dávali dobrý pozor" [lett. "Ik vroeg de studenten, opdat zij op de plaatjes goed opletten"]. De constructie van accusativus cum infinitivo komt in het Tsjechisch nauwelijks voor, vgl. Dušková (543-559), maar ook Dušková (440) waar wel over de voorzetselvoorwerpszin in het Engels wordt gesproken.

${ }^{3}$ Inmiddels is er een grondig herziene derde versie van de $A N S$ verschenen die uitsluitend online beschikbaar is op https://e-ans.ivdnt.org. De beschrijving van het voorzetselvoorwerp (https://e-ans.ivdnt.org/topics/pid/ans 2006lingtopic) is echter nog niet wezenlijk veranderd ten opzichte van de gedrukte versie van 1997.

${ }^{4} \mathrm{Er}$ is een nieuwe, herziene versie van deze spraakkunst in bewerking, de Velká akademická gramatika českého jazyka [Grote Academische Grammatica van de Tsjechische Taal]. Hiervan is inmiddels het eerste, morfologische deel in 2018 verschenen. 


\section{Definities}

De beschrijving van het voorzetselvoorwerp in de Algemene Nederlandse Spraakkunst (1997: 1168) klinkt al redelijk omineus: ${ }^{5}$

Het VOORZETSELVOORWERP is een zinsdeel dat bij bepaalde werkwoordelijke en naamwoordelijke gezegdes kan of moet voorkomen en de zelfstandigheid aanduidt waarop de door het gezegde uitgedrukte werking gericht is; het bestaat in principe altijd uit een voorzetselconstituent.

Het zinsdeel dat traditioneel als voorzetselvoorwerp bekend staat, heeft een omstreden status; zowel terminologisch als inhoudelijk is door taalkundigen bezwaar aangetekend tegen het begrip voorzetselvoorwerp.

Willy Vandeweghe wijdt in zijn Grammatica van de Nederlandse zin het gehele zevende hoofdstuk aan wat hij 'voorzetselobject' noemt. Hij stelt het volgende (Vandeweghe 2000: 95):

Het voorzetselobject kan eerste of tweede object zijn bij de zinsrelator, ${ }^{6}$ en het wordt met het zinspredikaat verbonden door middel van een vast voorzetsel. Met 'vast' is bedoeld dat het voorzetsel paradigmaloos is: niet vervangbaar, uitbreidbaar of weglaatbaar. Dat komt dan weer omdat het niet-autonoom is: het kan niet zelfstandig een betekenisvolle verbinding leggen, maar fungeert enkel betekenisvol in combinatie met het predikaat. Dat houdt in dat de voorzetselkeuze al mee geprogrammeerd is in de keuze van het predikaat: dat zit in het lexicon opgeslagen mét het bijpassende voorzetsel.

Voor de beginnende student-vreemdetaalleerder is de definitie van Jan Luif in zijn In verband met de zin wellicht simpeler:

[Voorzetselvoorwerpen] zijn te herkennen doordat ze beginnen met een voorzetsel dat een vaste combinatie vormt met het gebruikte werkwoord (Luif 22-23).

en:

Werkwoord en voorzetsel hebben in deze combinatie samen een eigen betekenis. Die betekenis kan sterk afwijken van de betekenis die ze buiten deze combinatie hebben (Luif 23).

Luif geeft in zijn grammatica, zoals in Nederland en Vlaanderen gebruikelijk is, steeds vervangingsproeven aan. Bij het voorzetselvoorwerp is dat:

Een voorzetselvoorwerp in de vorm van een voorzetselconstituent is bijna altijd te vervangen door een voorlopig voorzetselvoorwerp en een voorzetselvoorwerps-zin (Luif 132).

5 In de nieuwe elektronische versie $\$ 20.6 .1$ (https://e-ans.ivdnt.org/topics/pid/ans200601lingtopic). Bij navolgende voorbeelden is steeds alleen naar de bewuste paragraaf verwezen.

${ }^{6}$ Met de term zinsrelator geeft Vandeweghe aan wat in de ANS en in traditionele schoolgrammatica's meestal met gezegde wordt aangeduid en met predikaat bedoelt hij hetgeen waaraan iets (hier het voorzetsel) refereert. 
Een voorbeeld door hem gegeven:

Ze beschuldigden hem van lafheid

Ze beschuldigden hem ervan dat hij laf was.

tegenover:

Hij brulde het uit van de pijn.

*Hij brulde het ervan uit dat hij pijn had.

Overigens stelt Vandeweghe (2000: 96) vrij terecht:

Het voorzetsel is niet-autonoom en als zodanig paradigmaloos. Het reageert dan ook negatief op de klassieke paradigmatische operaties van vervanging, uitbreiding en weglating, en aangezien het niet contrasteerbaar is, is ook beklemtoning uitgesloten.

Vanuit de optiek van de student-vreemdetaalleerder zijn vervangingsoperaties niet echt behulpzaam en zelfs verwarrend. De vreemdetaalleerder 'voelt' immers, anders dan de meeste moedertaalsprekers, niet de (on)mogelijkheid van bepaalde vervangingsoperaties aan. In de praktijk betekent dit dat de studenten meestal hele reeksen werkwoorden 'met hun vaste voorzetsel' uit het hoofd moeten leren. Zoals vrijwel alle Slavische talen heeft het Tsjechisch een uitgebreid en actief gebruikt naamvalssysteem waarmee allerlei onderlinge verbanden in de zin kunnen worden aangeduid. Mede hierom bezit het Tsjechisch minder voorzetsels dan het Nederlands, waardoor de Tsjechische voorzetsels bij vertaling 'poly-interpretabel' zijn. Zo is het voor een Tsjechische leerder lastig uit te maken of bijvoorbeeld Tsjechisch $n a$ in het Nederlands moet worden vertaald met 'op' (de eerste betekenis), 'naar', 'aan' of 'voor' - betekenissen die allemaal voorkomen. ${ }^{7}$

\section{Het voorzetselvoorwerp in het Tsjechisch}

Ook syntactisch is er een probleem. Zowel voor moedertaalsprekers als voor studenten-vreemdetaalleerders is moeilijk invoelbaar of een bepaalde voorzetsel-constituent in de bewuste zin de functie heeft van een bijwoordelijke bepaling dan wel van een voorzetselvoorwerp. Hierbij komt het extra probleem dat het voorzetselvoorwerp in het Tsjechisch als verschijnsel wel degelijk bestaat, d.w.z. er zijn werkwoorden die in plaats van een object in de accusatief een objectsconstructie met een verplicht voorzetsel hebben, bijv. Myslel na matku [Hij dacht

7 Voorbeelden: na stole - 'op tafel'; jít na poštu - 'naar de post gaan'; na konci - 'aan het einde'; to je na ni moc - 'dat is te veel voor haar' (Máčelová-Van den Broecke \& Spěváková 360). Het omgekeerde komt overigens eveneens voor. Zo kan het Nederlandse voorzetsel 'voor' in het Tsjechisch pred, pro, za of na betekenen: 'voor het huis' - před domem; 'het is voor u' - to je pro Vás; 'voor die prijs' - za tu cenu; 'dat is goed voor de dorst' - to je dobré na žizeň (Čermák \& Hrnčířová 952-953). Dit is echter minder vaak het geval. 
aan moeder], maar dat dit verschijnsel niet apart is gecategoriseerd. In het derde, syntactische deel van de $M \check{C}$ vermelden de auteurs wel het volgende:

Vzorce s komplementem v předložkovém pádě představují velmi pestrý soubor, a to jak po stránce významové, tak formální. Z hlediska větněčlenského má komplement ráz objektový, nebo je ADV, zejména ADVLoc (MČ 193).

[Voorbeelden met een complement in een voorzetselnaamval vormen een zeer bont geheel, en dat zowel van de kant van de betekenis als formeel. Gezien vanuit de zinsbouw heeft het complement een objectskarakter, of het is adverbiaal, met name locatief-adverbiaal.]

Veel duidelijker is de recentere $P M \check{C}$ die het begrip 'předmět v pozici s formou předložkového pádu' munt, letterlijk 'object in positie met de vorm van een voorzetselnaamval'. Uit de beschrijving en de voorbeelden blijkt dat dit het Tsjechische equivalent van het Nederlandse voorzetselvoorwerp is (PMČ 432):

U předložkových pádů dochází $\mathrm{k}$ jejich postupnému přechodu z platnosti př́slovečné do platnosti předmětné. Ve vazebných pádech se užívá jen předložek původních, které v nich ztrácejí své více nebo méně konkrétní významové odstíny. Srov.: Myslel na matku (předložka na pozbyla svého původního významu "umístění na povrchu něčeho"). Naproti tomu v pádech nevazebných, tj. příslovečných, si původní předložky do značné míry ponechávají svůj původní význam: Sedl si na stůl (předložka na označuje "umístění na povrchu něčeho"). ${ }^{8}$

[Bij voorzetselnaamvallen komt het stapsgewijze tot een overgang van een bepalingswerking naar een objectwerking. In verbindende gevallen worden uitsluitend de oorspronkelijke voorzetsels gebruikt, die hierin min of meer hun concrete betekenis verliezen. Vergelijk: Myslel na matku - "Hij dacht aan zijn moeder" (het voorzetsel 'na' heeft zijn oorspronkelijke betekenis van 'positionering op het oppervlak van iets' verloren). Daarentegen behouden de oorspronkelijke voorzetsels in de niet-verbindende, dat wil zeggen bepalingsgevallen, voor een belangrijk deel hun oorspronkelijke betekenis: Sedl si na stůl - "Hij ging op de tafel zitten" (het voorzetsel 'na' betekent hier 'positionering op het oppervlak van iets'].

De voorbeelden die Karlík e.a. (2012) vervolgens geven in concurrerende paren van wat wij voorzetselvoorwerp en bijwoordelijke bepaling zouden noemen, geven aan dat ook het Tsjechisch tot vergelijkbare structuren komt. Helaas is deze precieze labeling als een apart syntactisch fenomeen tot nog toe nog niet in de Tsjechische schoolgrammatica's doorgedrongen. Het probleem wordt daar (soms) wel besproken, maar zonder dat het een duidelijk eigen label krijgt. Tsjechische schoolgrammatica's onderscheiden hoofdzakelijk tussen základni větné členy, basiszinsdelen, waarmee přisudek [gezegde] en podmět [onderwerp] zijn bedoeld (Styblík 83-86), en rozvíjejicí větné členy [uitbreidende zinsdelen] die zijn gelabeld als předmět [object], př́slovečné určeni [bijwoordelijke bepaling], př́vlastek [lett. 'attribuut'] en doplněk [lett. 'aanvulling']. Een belangrijk probleem is dat de laatste twee Tsjechische categorieën absoluut niet overeenkomen met klassieke Nederlandse zinsdelen. Zo worden in het zinnetje "Na úpatí hory

${ }^{8}$ Letterlijk dezelfde uitleg geven ook Grepl en Karlík (245). 
stojí stromy se zažloutlými listy" (Styblík 86) [Aan de voet van de berg staan bomen met vergeelde bladeren] zowel hory [van de berg] als zažloutlými [vergeelde] als prívlastek en daarmee als apart zinsdeel geclassificeerd. ${ }^{9}$ In beide gevallen gaat het om zinsdeelstukken die in het Nederlands hooguit als bijvoeglijke bepaling worden benoemd (Luif 68, 136) maar meestal niet apart worden geclassificeerd. Onder het hoofdje doplněk vallen types constituenten die in het Nederlands meestal als bepaling van gesteldheid (ANS 1997: 1183-1189) worden gedetermineerd. ${ }^{10}$

Het attribuut wordt in het Tsjechisch, zoals gezegd, als een apart zinsdeel beschouwd. Tsjechische basisschoolleerlingen leren dat "bijwoordelijke bepalingen voorrang hebben boven voorwerpen" en antwoord geven op de vragen Kde? [Waar?], Kam? [Waarheen?], Odkud? [Waarvandaan?] en dergelijke.

$\mathrm{Nu}$ gaat het bij bovengenoemde situatie om een schoolgrammatica. Het Tsjechische equivalent van Luif (2011) of Vandeweghe (2000) is Robert Adam, Gramatické rozbory češtiny (2017) [Grammaticale analyses van het Tsjechisch], een grammatica die voornamelijk bestemd is voor bachelorstudenten Tsjechisch. Helaas is vanuit een Nederlandse optiek bekeken de beschrijving in dit werk nauwelijks duidelijker.

Hierin wordt de categorie predmět [object] als volgt omschreven:

Předmět (objekt) je větný člen, jehož pádová forma je pevně fixována řídícím slovesem nebo adjektivem, tj. určena vztahem rekce. (...) Na předmět se ptáme všemi pádovými otázkami kromě $k d o, c o$. Od podmětu se předmět liší tím, že pozici předmětu mají i slovesa $\mathrm{v}$ jiném tvaru než určitém (Upéct koláč už nestihla. Pekouc koláč, zpívala si.) a verbální adjektiva (Přri pozorováni mámy pečici koláč se mu sbíhaly sliny.) a že předmět se může ve větě vyskytovat více než jednou (Daroval jim křeslo. - dva předměty řízené jedním slovesem; Nař́dila $\boldsymbol{m u}$ upéct koláč. - tři předměty, první dva řízené verbem finitem, třetí infinitivem) (Adam 106).

[Een voorwerp (object) is een zinsdeel, waarvan de naamvalsvorm geheel gefixeerd is door het leidende werkwoord of adjectief, dwz. bepaald door de relatie van de rectie. (...) Naar het voorwerp vragen we met alle naamvalsvragen behalve 'wie', 'wat'. Het onderwerp verschilt van het voorwerp doordat de voorwerpspositie ook door werkwoorden kan worden ingenomen in een andere dan de finiete vorm (Ze haalde het niet meer een cake te bakken. De cake bakkende zong ze.) en door verbale adjectiva (Bij het observeren van de een cake bakkende

9 Overigens onderscheidt het Tsjechisch twee types prrivlastek en wel přivlastek shodný [congruent attribuut] en př́vlastek neshodný [niet-congruent attribuut]. In het geciteerde voorbeeld is in de constructie na úpati hory het woord hory een niet-congruent attribuut, omdat het in een andere naamval staat dan úpatí en dus als het ware een extra toevoeging is. In se zažloutlými listy is zažloutlými een congruent attribuut, aangezien het in dezelfde naamval en hetzelfde getal staat als listy, waar het bij hoort.

${ }^{10}$ Luif onderscheidt strikt tussen 'bepaling van gesteldheid' voor de toestand tijdens de handeling (Luif 51-52) - ANS (1184-1186; vgl. ANS 2021 \$20.9.2) noemt dit 'bepaling van gesteldheid tijdens de handeling', en predicatief complement, namelijk de toestand als resultaat van de handeling (Luif 44) - ANS (1187-1189; vgl. ANS 2021 \$20.9.3) geeft hiervoor het begrip 'bepaling van gesteldheid ten gevolge van de handeling'. In het Tsjechisch is beide doplněk. 
moeder liep het water hem in de mond.) en doordat er in de zin meer dan één voorwerp kan voorkomen (Hij gaf hun een fauteuil. - twee voorwerpen geregeerd door één werkwoord; Ze beval hem een taart te bakken. - drie voorwerpen, de eerste twee geregeerd door een finiet werkwoord, de derde door een infinitief)].

Het duidelijkste is nog het naslagwerkje voor groot publiek van de firma Lingea, Gramatika současné češtiny (2018) [Grammatica van het moderne Tsjechisch] dat het voorwerp als volgt verklaart:

Předmět neboli objekt je rozvíjející větný člen, rozvíjí sloveso nebo přídavné jméno. Předmět se nejčastěji vyjadřuje podstatným jménem nebo zájmenem ve 4. pádu (může být i ve 2., 3., 7. pádu), lze ho vyjádřit i infinitivem. (...)

Předmět v predložkovém pádu

O předmět se jedná, pokud se sloveso pojí jen s jednou předložkou:

Odkázal mé na nadř́zeného (odkázat na +4 . pád)

Poprosil mě o vodu. (poprosit o + 4. pád)

Raduji se z úspěchu svých dètí. (radovat se $z+2$. pád)

Nejraději vykládal o své motorce (vykládat o + 6. pád) (...)

V některých mluvnicích jsou vazby s předložkovým pádem chápány ne jako předmět, ale jako prŕslovečné určení. Přesnou hranici mezi nimi nelze určit (Lingea 2018: 184, 186).

[Een voorwerp of object is een uitbreidend zinsdeel, het ontwikkelt een werkwoord of een bijvoeglijk naamwoord. Het voorwerp wordt meestal uitgedrukt door een zelfstandig naamwoord of voornaamwoord in de $4^{\mathrm{e}}$ naamval (het kan ook in de $2^{\mathrm{e}}, 3^{\mathrm{e}}, 7^{\mathrm{e}}$ naamval zijn), het kan ook worden uitgedrukt door een infinitief. (...)

Voorwerp in de voorzetselnaamval

Het gaat om een voorwerp, indien het werkwoord steeds met slechts één voorzetsel wordt verbonden:

Hij verwees me naar mijn meerdere (verwijzen naar $+4^{e}$ naamval)

Hij vroeg me om water. (vragen om $+4^{e}$ naamval)

Ze verheugen zich over het succes van hun kinderen. (zich verheugen over $+2^{e}$ naamval)

Hij vertelde het liefst over zijn motorfiets (vertellen over $+6^{e}$ naamval) (...)

In sommige grammatica's worden verbindingen met een vast voorzetsel niet begrepen als een voorwerp, maar als een bijwoordelijke bepaling. De exacte grens daartussen kan niet worden bepaald].

Hieruit wordt al iets duidelijk. Om te beginnen is de grens tussen voorzetselvoorwerp en bijwoordelijke bepaling in het Tsjechisch voor Tsjechische leerlingen en studenten in enkele gevallen even onduidelijk als die in het Nederlands voor Nederlandstalige studenten is. Ook Nederlandse wetenschappers strijden erover of bij een bepaalde voorzetselconstructie als bijv. "Ik zoek naar een goede vulpen" de voorzetselconstituent nu wel of geen voorzetselvoorwerp is (Duinhoven 51, vgl. Schermer-Vermeer 2006: 156). ${ }^{11}$ Ten tweede wordt het bepalen van zinsdelen op school evenals in Tsjechië gedaan door vragen te stellen: "Wie doet iets?" (onderwerp). "Wat wordt gedaan?" (direct object). "Aan

11 De overeenkomstige Tsjechische constructie Pátrám po dobrém plnicím peru wordt meestal als 'voorwerpsconstructie' gezien. 
wie wordt iets gegeven?" (indirect object). Als we echter bijvoorbeeld de vraag 'Waaraan?' stellen, kan dit zowel met een voorzetselvoorwerp (bijv. "Ik denk aan mijn vakantie"), als met een bijwoordelijke bepaling (bijv. "Het schilderij hangt aan een spijker") verband houden. Het antwoord op de vragen geeft wel aan wat bij een bepaald werkwoord hoort maar niet welke functie het heeft - hetgeen in Tsjechische grammatica's een minder groot probleem is, aangezien eerst de vraag naar de bijwoordelijke bepalingen wordt gesteld (die dan al gedetermineerd zijn), terwijl het verschil tussen verschillende types predmět voor het Tsjechisch minder relevant en feitelijk uit de naamvallen al duidelijk is. Voor Tsjechen gaat het er wat de voorwerpen betreft met name om het basale verschil tussen onderwerp en voorwerp te maken. Deze voor West-Slavische talen logische aanpak is echter een wijze van determineren die bij het leren van analytische talen als het Engels en het Nederlands problematisch kan zijn, aangezien hier het verschil tussen de verschillende types objecten wel van belang is en dit, ook voor moedertaalsprekers, vaak lastiger is vanwege het feitelijk ontbreken van naamvallen. Zoals hierna zal worden verduidelijkt, begint daar in recentere Tsjechische academische spraakkunsten verandering in te komen.

Dankzij toenemend belang van het Engels als vreemde taal wordt gezocht naar andere manieren om syntaxis te onderwijzen (Zouharová 2005). Er is een nieuwe academische grammatica op komst waarvan vooralsnog voorstudies in de vorm van de serie Studie k moderní mluvnici češtiny [Studies voor een moderne grammatica van het Tsjechisch] onder leiding van Oldřich Uličný en zijn collega's beschikbaar zijn. ${ }^{12}$ In het deel "Preliminária" (Uličný 281-282) komt het probleem van de pád lexikální vyjádřený předložkovou skupinou [lexicale naamval uitgedrukt met een prepositionele groep] aan de orde met een hele serie voorbeelden uit het elektronische Tsjechische Nationale Corpus.

\section{De functie van het voorzetsel}

Wat in vrijwel alle grammatica's in beide talen ontbreekt, is waarom er in een voorzetselvoorwerp juist een voorzetsel staat in deze constructie. Broekhuis en collega's stellen op Taalportaal (Syntax 2.3):

The one thing that all researchers seem to agree on is that the verb and the preposition that heads the PP-complement form a semantic unit, that is, express a lexically determined meaning; the meaning of the prepositions in isolation is lost. For example, the functional prepositions op and voor in the primeless examples in Jan wacht op zijn vader / Jan vecht voor een betere wereld do not have the locational meanings of the prepositions op and voor in the primed examples Jan wacht op het perron / Jan vecht voor de school.

12 Zie noot 4. 
Vandeweghe (2000: 95-96) stelt: "in tegenstelling echter tot bij een direct object of een indirect object, impliceert het werkwoord niet dat X geaffecteerd wordt of enigerlei verandering ondergaat door de werking". De gedachte daarbij is duidelijk: Vandeweghe ziet het voorzetsel als een element dat het object op een zekere afstand zet. Dat voorzetsel moet dus toch wel enige betekenis of functie hebben, al is die wellicht slechts rudimentair (ook voor het Tsjechisch spreekt Karlík e.a. 359 van desémantizace). Grepl en Karlík (249) geven een uitleg die aan die van Vandeweghe doet denken:

Různým valencím jednoho slovesa odpovídají různé predikátory, ${ }^{13}$ které spolu souvisejí a mezi nimiž je často jen velmi jemný rozdíl. Např. vidět něco a vidět na něco mají společné to, že označují smyslový vjem, a liší se tím, že vidět na něco vyjadřuje navíc "překonávání překážky".

[Verschillende valenties van één werkwoord komen overeen met verschillende predicators, die met elkaar in verband staan en waartussen vaak slechts een heel subtiel verschil bestaat. Bijv. iets zien en naar iets kijken hebben gemeen dat ze zintuiglijke waarneming aangeven, en verschillen daarin dat het kijken naar iets ook 'een obstakel overwinnen' uitdrukt].

Bij verder doordenken valt op dat er voor voorzetselverbindingen vaak een alternatief werkwoord mogelijk is met een direct object, en dat door toevoeging van een niet-afscheidbaar voorvoegsel van het werkwoord met verplicht voorzetselvoorwerp vaak ook een overgankelijk werkwoord met direct object kan worden gemaakt, een procédé dat in het Duits als Valenzänderung bekend staat (Fabricius-Hansen 689-690; ${ }^{14}$ ANS 596, vgl. ANS 2021, § 2.2.3):

— De studenten zien het bord.

- De studenten kijken naar het bord.

- De studenten bekijken het bord.

- De leraar noemt het voorzetselvoorwerp.

- De leraar spreekt over het voorzetselvoorwerp.

- De leraar bespreekt het voorzetselvoorwerp.

- De politicus vermijdt grote fouten.

— De politicus hoedt zich voor grote fouten.

Voorts zijn er gevallen, waarbij één en hetzelfde werkwoord zowel met een direct object als met een voorzetselvoorwerp kan worden geconstrueerd:

- Hij zocht zijn vulpen.

- Hij zocht naar zijn vulpen.

13 Het begrip predikátor heeft geen terminologische equivalent in de ANS. Het komt wezenlijk overeen met het begrip 'zinsrelator' bij Vandeweghe (2000: 43), vgl. Grepl en Karlík (30-31).

${ }^{14}$ In oudere Duitse handboeken is sprake van Aktionsartdifferenzierung (vgl. Drosdowski e.a. 419), hetgeen iets preciezer aangeeft wat hier aan de hand is. Zoals Fabricius-Hansen (408) opmerkt, is "die Fachterminologie zum Thema Aktionsart sehr uneinheitlich und verwirrend". 
In al deze gevallen geeft het in de prepositionele verbinding gebruikte werkwoord een grotere intensiteit van de handeling aan. Als ik mijn vulpen zoek, weet ik vermoedelijk wel ongeveer waar die ligt en kijk ik op die plekken. Maar als ik naar mijn vulpen zoek, weet ik wel dat ik er een heb, maar heb ik er geen flauw idee van waar ik die heb gelaten. Als studenten een bord zien, doen ze dat bij wijze van spreken onwillekeurig, zonder er moeite voor te doen. Maar als ze ernaar kijken, moeten ze hun aandacht erop richten, vergelijk:

— Terwijl hij naar de klok keek, zag hij een spin op de muur.

Het voorzetsel heeft dus minimaal een rudimentaire betekenis van richting, waarbij die richting aangeeft waarop en hoe de aandacht wordt gericht. Het duidelijkste is dat in geval van werkwoorden met dezelfde lexicale basis waarbij het éne met direct object (en met een niet-afscheidbaar voorvoegsel) transitief is en het andere met een prepositioneel object intransitief:

- Jan betreurt de nederlaag van zijn club.

- Jan treurt om de nederlaag van zijn club.

- Marie bekijkt de foto's van de vakantie.

- Marie kijkt naar de foto's van de vakantie.

- Susan en Piet verwachten de trein van tien over drie.

- Susan en Piet wachten op de trein van tien over drie.

In alle gevallen is de versie van het werkwoord met een prepositioneel object intensiever - de betekenis van het voorzetsel is dus een indicator van intensiteit. Kortom, het is de vraag of de opmerking van Broekhuis en collega's (Syntax 2.3) "Consequently, it may sometimes be hard to use semantic criteria as evidence for one position or another" echt juist is. Bij vertaling naar een vreemde taal komen juist die semantische waarden tot uitdrukking - althans indien de vertaling adequaat is. Juist omdát het voorzetsel minimaal rudimentair ook een betekenis heeft, ontstaat bij leerlingen verwarring met de bijwoordelijke bepaling. Bijwoordelijke bepalingen worden immers gevormd met vergelijkbare prepositionele constituenten waarin óók een richting wordt aangegeven die bovendien vaak bij dezelfde voorzetsels eveneens met intransitieve werkwoorden verbonden is:

- De student keek naar het bord met de moeilijke sommen.

— De student ging naar het bord met de moeilijke sommen.

Hier biedt zich voor enkelvoudige zinnen voor de Tsjechische tweedetaalspreker van het Nederlands wel degelijk een proef aan - vertalen:

- Student se dival na tabuli s těžkými početními úkoly.

- Student šel $\boldsymbol{k}$ tabuli s těžkými početními úkoly.

In het eerste geval 'voelt' de Tsjechische student dat hij met een object met een voorzetselnaamval te maken heeft - door het vele inoefenen in lagere onderwijsfases zit dat als het ware erin gehamerd, al weet de student niet waarom dit 
zo is. En in het tweede geval 'voelt' hij de richting. Desondanks is het goed te kijken of er betere criteria zijn om vast te stellen of we met een voorzetselvoorwerp te maken hebben.

\section{Het criteriadebat}

Zowel Hans Broekhuis en Ina Schermer-Vermeer als Willy Vandeweghe hebben zich in het voorzetselvoorwerp vastgebeten en pogingen gedaan om criteria te vinden die uitsluitend toepasbaar zijn op het voorzetselvoorwerp. Broekhuis (2004) stelt dat een 'waterdicht criterium' onbereikbaar is en komt vervolgens tot een uitgebreide classificatie van verschillende types voorzetselvoorwerp nemende (meestal intransitieve) werkwoorden. Deze gedetailleerde classificatie voert voor dit artikel wat te ver. Ina Schermer-Vermeer (2006: 156) reageerde daarop met een voorstel om een ander begrip te gaan gebruiken, namelijk 'niet-predicatieve complementaire voorzetselbepaling', omdat sommige bijwoordelijke bepalingen ook niet-weglaatbaar zouden zijn. Hierna volgde een vrij intensieve discussie, waarin ook Vandeweghe zich later mengde.

De kern van het debat draaide om welke criteria er kunnen worden opgesteld, zodat duidelijk kan worden gesteld of iets voorzetselvoorwerp dan wel bijwoordelijke bepaling is. Vandeweghe probeerde in zijn alleen online gepubliceerde overzicht Categorieën van predicaten met voorzetselvoorwerp (2014) een en ander nog eens overzichtelijk op een rij te zetten. Indien het mogelijk zou zijn om inderdaad waterdichte criteria op te stellen voor wanneer een voorzetselconstituent als voorzetselvoorwerp fungeert en wanneer als bijwoordelijke bepaling, zou dit alle 'deelnemers aan het taalverkeer' zeer behulpzaam zijn, of zij nu moedertaalsprekers dan wel tweede- of vreemdetaalleerders zijn.

\section{Ter afronding}

Als we nu een poging doen om een en ander voor de Tsjechische vreemdetaalleerder van het Nederlands inzichtelijk te maken, kan puntsgewijze het volgende worden gesteld:

1. Voorzetselvoorwerpen komen meestal voor bij intransitieve werkwoorden die dankzij het gebruik van deze constructie zo een object kunnen krijgen - namelijk het voorzetselvoorwerp. Uit met name Grepl en Karlík (1998), Karlík (2000) en Karlík e.a. (2012), blijkt dat soortgelijke werkwoorden in het Tsjechisch eveneens bestaan. Het object is door Karlík e.a. en Grepl en Karlík geclassificeerd als předmět v pozici s formou předložkového pádu. Dušková $(39,442)$ gebruikt een precieze vertaling predmět předložkový, Kluková (128) doet dat eveneens, zij het met een internationalisme, prepozicionálni objekt. 
2. Voorzetselvoorwerpen zijn als typische objecten meestal niet weglaatbaar, zij zijn dus een 'complement' en geen 'satelliet', zoals de bijwoordelijke bepaling dit meestal wel is.

3. Voorzetselvoorwerpen kunnen net als directe objecten in een gepassiveerde zin voorkomen. Anders dan directe objecten worden zij dan echter geen subject, maar verschijnt er een constructie met ompersoonlijk passief die een zekere parallellie vertoont met de voorzetselvoorwerpszinsproef van Luif:

De leerlingen keken met verbazing naar de voorbeelden op het bord.

Er werd door de leerlingen met verbazing naar de voorbeelden op het bord gekeken.

Verg. De leerlingen keken ernaar met verbazing dat de voorbeelden op het bord stonden.

De parallellie is gelegen in het feit dat 'er' hier verwijst naar 'naar de voorbeelden'. Dit wordt in het Nederlands gewoonlijk niet als een 'gekloofd subject' of iets dergelijks beschouwd.

4. Semantisch gezien vormt het voorzetsel één geheel met het werkwoord. Het is zonder betekenisverandering niet vervangbaar door een ander voorzetsel.

5. In specifieke gevallen, het duidelijkste geclassificeerd in Vanweghe (2014), kunnen er in een zin twee voorzetselvoorwerpen bij één werkwoord voorkomen. Het gaat dan om zinnen als "Wij praten met hen over het voorzetselvoorwerp". Hierbij moet worden opgemerkt dat veel taalkundigen als Hans Broekhuis (2014) net als de ANS (1179; ANS 2021 §20.6.1 sub 3, https://e-ans.ivdnt.org/topics/pid/ ans200601ling topic) ervan uitgaan dat er maximaal één voorzetselvoorwerp in de zin kan staan. De voorzetselgroep 'met hen' wordt dan als een 'comitatieve bijwoordelijke bepaling' gezien. De Tsjechische vertaling - "Mluvíme s nimi o předložkovém předmětu" - lijkt overigens Vandeweghe gelijk te geven, want volgens de Tsjechische classificatie wordt s nimi hier eveneens als een předmět [voorwerp] opgevat.

6. Bij enkele werkwoorden als 'iemand herinneren aan iets' is zelfs de combinatie van een direct object met een voorzetselvoorwerp mogelijk, zoals Vandeweghe (2014: 3) beargumenteert. Dit komt overeen met wat Dušková (442-443) voor het Engels vaststelt. Dezelfde constructie is eveneens in het Tsjechisch mogelijk: upomínat někoho o něco is qua constructie een volledig equivalent.

Voor Tsjechische studenten is het voorzetselvoorwerp het gemakkelijkste te herkennen op basis van punt 1 en punt 4 . Bij het eerste door te vertalen, waarbij vaak (maar niet altijd) ook in het Tsjechisch een vergelijkbare constructie die is geclassificeerd als predmět (object) verschijnt - in afwijkende gevallen is er in het Tsjechisch meestal een direct object. Punt 4 betekent dat de studenten lijsten van werkwoorden met hun vaste voorzetsel uit het hoofd moeten leren.

Verder comparatief onderzoek zou verbanden tussen de gebruikte voorzetsels in zowel het Nederlands als het Tsjechisch kunnen aantonen, waarbij in beide gevallen een ruim en actueel corpus onderzocht moet worden. Hierbij moet de aandacht met name worden gericht op regelmaat in de vaste voorzetsels, omdat 
de praktijk leert dat het Nederlandse vaste voorzetsel meestal vanuit een Tsjechisch standpunt als 'onlogisch' wordt ervaren - studenten hebben de neiging om het dichtstbijzijnde equivalent van het Tsjechische vast voorzetsel te nemen. Een dergelijk vergelijkend onderzoek zou in een ideaal geval direct ook voor een vergelijkbare West-Slavische taal als het Pools moeten worden uitgevoerd.

\section{Bibliografie}

Beliën, Maaike, en Frank Landsbergen, editors. Algemene Nederlandse Spraakkunst, $3^{\mathrm{e}}$ editie (uitsluitend online), gestart 2021, https://e-ans.ivdnt.org/. Geraadpleegd 29 juli 2021. In de tekst ANS 2021.

Broekhuis, Hans. "Dubbel-voorzetselconstructies?" Patroon en argument. Een dubbelfeestbundel bij het emeritaat van William van Belle en Joop van der Horst, geredigeerd door Freek van de Velde et al. UP Leuven, 2014, pp. 103-114.

---. "Het voorzetselvoorwerp". Nederlandse Taalkunde, vol. 9, no. 2, 2004, pp. 97-131.

---. "Worstelen met het voorzetselvoorwerp: opmerkingen bij Ina Schermer-Vermeers artikel". Nederlandse Taalkunde, vol. 12, no. 4, 2007, pp. 351-358.

Broekhuis, Hans, et al., editors. Syntax of Dutch. Verbs and Verb Phrases, vol. 1. Amsterdam University Press, 2015.

---. Taalportaal. The linguistics of Dutch, Frisian and Afrikaans online. Hiervan: Syntax \$2.3 PP-complements (prepositional objects), http://taalportaal.org/taalportaal/topic/link/syntax_Dutch vp_V2_complementation_V2_complementation.2.3.xml. Geraadpleegd 29 juli 2021.

Čermák, František, en Zdeňka Hrnčířová. Nizozemsko-český slovnik / Nederlands-Tsjechisch woordenboek, $3^{\mathrm{e}}$ druk, Leda, 2005.

Daneš, František, et al., editors, Mluvnice češtiny 3. Skladba. Praha: Academia, 1987.

Drosdowski, Günther, et al., editors. Duden. Grammatik der deutschen Gegenwartssprache, $4^{\mathrm{e}}$ druk. Dudenverlag, 1984.

Duinhoven, Antonius M. "Het voorzetselvoorwerp. Een zinspatroon in wording”. De nieuwe taalgids, vol. 82, no. 1, 1989, pp. 40-56.

Dušková, Libuše, redactor. Mluvnice současné angličtiny na pozadí češtiny. Praha: Academia, 2012.

Fabricius-Hansen, Cathrine. "Das Verb". Duden. Die Grammatik. Unentbehrlich für richtiges Deutsch, geredigeerd door Kathrin Kunkel-Razum en Franziska Münzberg, $8^{\mathrm{e}}$ verbeterde druk. Dudenverlag, 2009, pp. 389-566.

Grepl, Miroslav, en Petr Karlík. Skladba češtiny. Votobia, 1998.

Haeseryn, Walter, et al., editors. Algemene Nederlandse Spraakkunst, $2^{\mathrm{e}}$ herziene druk. Martinus Nijhoff en Wolters-Plantyn, 1997. In de tekst ANS.

Karlík, Petr. "Hypotéza modifikované valenční teorie". Slovo a slovesnost, vol. 61, no. 3, 2000, pp. $170-189$.

---. "Předmět (objekt)". Encyklopedický slovník češtiny, geredigeerd door Petr Karlík et al. Nakladatelství Lidové noviny, 2002, pp. 350-351.

Karlík, Petr, et al., editors. Př́ruční mluvnice češtiny, $4^{\mathrm{e}}$ druk. Nakladatelství Lidové noviny, 2012.

Kluková, Markéta. "Syntax nizozemského jazyka”. Capita Selecta z nizozemské lingvistiky, geredigeerd door Kateřina Křížová. Univerzita Palackého v Olomouci, 2017, pp. 115-137.

Kolektiv LINGEA. Gramatika současné češtiny, $2^{\mathrm{e}}$ druk. Lingea, 2018.

Luif, Jan. In verband met de zin, $5^{\mathrm{e}}$ druk. Amsterdam University Press, 2011.

Máčelová-Van den Broecke, Emmy en Dana Spěváková. Česko-nizozemský slovnik / TsjechischNederlands Woordenboek. $2^{\mathrm{e}}$ druk, Leda, 2005. 
Robert, Adam. Gramatické rozbory češtiny. Výklad a cvičení s řešeními. Karolinum, 2017.

Schermer-Vermeer, Ina. "Worstelen met het voorzetselvoorwerp". Nederlandse Taalkunde, vol. 11, no. 2, 2006, pp. 146-183.

---. "Worstelen rond het voorzetselvoorwerp: een reactie op de opmerkingen van Hans Broekhuis". Nederlandse Taalkunde, vol. 12, no. 4, 2007, pp. 358-365.

Styblík, Vlastimil, et al. Český jazyk pro 8. ročník základni školy a pro odpovídajicí ročníky víceletých gymnázií, 4e druk. SPN - pedagogické nakladatelství, 2005.

Uličný, Oldřich, et al. Preliminária k moderní mluvnici češtiny. Univerzita Palackého v Olomouci, 2015.

Vandeweghe, Willy. Categorieën van predicaten met voorzetselvoorwerp, 2014, https://sites. uclouvain.be/bkl-cbl/wp-content/uploads/2014/08/vdw20111.pdf. Geraadpleegd 29 juli 2021.

---. Grammatica van de Nederlandse zin, $8^{\mathrm{e}}$ druk. Garant, 2000.

---. "Het voorzetselvoorwerp en de hiërarchie der objecten". Nederlandse Taalkunde, vol. 16, no. 1, 2011, pp. 88-101.

Zouharová, Marie. Inovace, organizace a prezentace syntaktických termínů v učivu českého jazyka na základní škole. Univerzita Palackého v Olomouci, 2005. 